\title{
Óriás mellékvesetumorok eltávolítása laparoszkópos transperitonealis technikával három sikeres eset kapcsán
}

\author{
Ottlakán Aurél dr. - Paszt Attila dr. - Borda Bernadett dr. \\ Simonka Zsolt dr. - Ábrahám Szabolcs dr. - Lázár György dr. \\ Szegedi Tudományegyetem, Általános Orvostudományi Kar, Sebészeti Klinika, Szeged
}

\begin{abstract}
A laparoszkópos adrenalectomia fejlődésével a benignus, kisméretú elváltozásokra korlátozódó indikációs kör mára nagyobb malignus mellékvesetumorok eltávolítására is kiterjed. Három esetben vizsgáltuk óriás $(>10 \mathrm{~cm})$ mellékvesedaganatok laparoszkópos eltávolításának eredményeit. Módszer: Három betegnél (két nő, egy férfi; átlagéletkor 49,33 év, BMI 31) végeztünk óriás méretü (>10 cm) mellékvese-elváltozás miatt laparoszkópos transperitonealis adrenalectomiát, kisméretű kiegészítő Pfannenstiel-metszésből. Az átlagos mútéti idő 126,66 perc volt, $150 \mathrm{ml}$ átlagos intraoperatív vérveszteséggel. A végleges szövettani vizsgálat két esetben adrenocorticalis carcinomát, egy esetben neurofibromát igazolt. Az átlagos kórházi tartózkodás négy nap volt, perioperatív szövődmény nélkül. Mindhárom esetben R0 reszekció történt. Az átlagos 24 hónapos utánkövetés során sem lokális recidívát, sem távoli metasztázisképződést nem észleltünk. Megfelelő feltételek esetén, nagyméretű malignus mellékvesetumorok laparoszkópos transperitonealis technikával történő eltávolítása biztonságos és az onkológiai irányelveket maradéktalanul kielégítő eljárás. Orv Hetil. 2017; 158(45): 1802-1807.
\end{abstract}

Kulcsszavak: mellékvesetumor, óriás, laparoszkópia, transperitonealis

\section{Removal of giant adrenal tumors using the laparoscopic transperitoneal technique}

\section{A report of three successful cases}

With the development of laparoscopic adrenalectomy, indications for resection gradually span from small and benign to bigger and even malignant lesions. We studied the results of laparoscopic adrenalectomy for giant $(>10 \mathrm{~cm})$ adrenal tumors in three cases. Three patients ( 2 female, 1 male, mean age 49.33 years, BMI 31 ) underwent laparoscopic transperitoneal adrenalectomy due to giant $(>10 \mathrm{~cm})$ adrenal lesions with a limited size Pfannenstiel incision.

Mean operative time was 126.66 minutes, with a mean intraoperative blood loss of $150 \mathrm{ml}$. Final histology confirmed adrenocortical carcinoma in two cases, and neurofibroma in one case. Mean hospital stay was 4 days, without perioperative complications. R0 resection was carried out in all cases. During a mean follow-up period of 24 months no local or distant metastasis occurred.

Under appropriate conditions adrenalectomy performed by the laparoscopic transperitoneal technique for giant malignant tumors proved to be a safe method fulfilling oncological requirements.

Keywords: adrenal, tumor, giant, laparoscopy, transperitoneal

Ottlakán A, Paszt A, Borda B, Simonka Zs, Ábrahám Sz, Lázár Gy. [Removal of giant adrenal tumor susing the laparoscopic transperitoneal technique. A report of three successful cases]. Orv Hetil. 2017; 158(45): 1802-1807.

(Beérkezett: 2017. augusztus 22.; elfogadva: 2017. szeptember 21.)

\section{Rövidítések}

ACC $=$ adrenocorticalis carcinoma; ACTH $=($ adrenocorticotropic hormone) adrenokortikotrop hormon; ASA = (American Society of Anesthesiologists) Aneszteziológusok Amerikai
Társasága; $\mathrm{BMI}=($ body mass index $)$ testtömeg-index; $\mathrm{CT}=$ (computed tomography) komputertomográfia; ESES $=($ European Society of Endocrine Surgeons) Endokrin Sebészek Európai Szövetsége; MEN = (multiple endocrine neoplasia $)$ 
multiplex endokrin neoplasia; $\mathrm{MI}=$ minimálisan invazív; MRI $=($ magnetic resonance imaging $)$ mágneses rezonanciás képalkotás; NIH = (National Institutes of Health) Nemzeti Egészségügyi Intézet; NSAID = (nonsteroidal anti-inflammatory drug) nem szteroid gyulladáscsökkentő; NYA = nyitott adrenalectomia; RP = retroperitonealis; SAGES $=($ Society of American Gastrointestinal and Endoscopic Surgeons) Amerikai Gasztroenterológus és Endoszkópos Sebész Társaság; TP = transperitonealis; $\mathrm{UH}=$ ultrahang; VMS = vanil-mandulasav

Nagyméretú mellékvese-elváltozások $(>6 \mathrm{~cm})$ viszonylag ritkán fordulnak elő (incidencia: 8,6-38,6\%) és közel 25\%-ban malignusak [1]. Amióta 1992-ben Michel Gagner és mtsai transperitonealis behatolásból elvégezték az első laparoszkópos adrenalectomiát, számos tanulmány alátámasztotta a minimálisan invazív (MI) módszer előnyeit a nyitott adrenalectomiával (NYA) szemben $[2,3]$. Az MI-technika elterjedésével a transperitonealis (TP) és a retroperitonealis ( $\mathrm{RP})$ módszer vált leginkább népszerúvé $[1,4,5]$. A TP-technikát kezdetben csak a kisméretű, illetve benignus mellékvese-elváltozások kezelésére ajánlották, amely indikációs kör fokozatosan kibővült a nagyméretű, illetve malignus elváltozások irányába. Az utóbbiak tekintetében jelenleg sincsen egyértelmű konszenzus. Egyes sebészi iskolák válogatott esetekben a laparoszkópos módszert ajánlják, míg mások kiterjesztett, nyitott mütétet javasolnak [6]. Az MI-technika számos előnnyel rendelkezik a nyitott módszerrel szemben, úgymint csökkent posztoperatív fájdalom, rövidebb kórházi tartózkodás, illetve felépülési idő, alacsonyabb szövődményráta, valamint esztétikai előnyök [7]. Mindazonáltal meg kell említeni, hogy bármely módszerról is legyen szó, az onkológiai radikalitás, illetve az R0 reszekció elsődleges a sebészi kezelésben. Tanulmányunkban három beteg kapcsán óriás méretú $(>10 \mathrm{~cm})$ mellékvesetumorok MI-módszerrel történt eltávolítását mutatjuk be, amelyek során minden esetben megfelelő onkológiai radikalitással R0 reszekciót végeztünk, igazolva, hogy a laparoszkópos transperitonealis módszer akár óriás méretű neoplasmák eltávolítására is sikeresen alkalmazható.

\section{Esetismertetés}

Intézetünkben három betegnél (két nő, egy férfi) távolítottunk el óriás mellékvese-daganatokat laparoszkópos transperitonealis technikával.

Az első egy 40 éves nőbeteg, fél éve bal vesetáji fájdalomról, hőhullámokkal járó rosszullétrôl, éjszakai izzadásról, valamint palpitatióról számolt be. Az elvégzett hasi CT- (komputertomográfia) vizsgálaton a bal mellékvesében lévő $10 \times 7 \times 8 \mathrm{~cm}$-es képlet jelent meg (1.ábra). Preoperatívan elvégzett endokrinológiai vizsgálatok során a szérumtesztoszteron-, illetve dehidroepiandroszteron-szulfát-szintek bizonyultak magasabbnak, amelynek alapján hormonálisan aktív elváltozást véleményeztek.

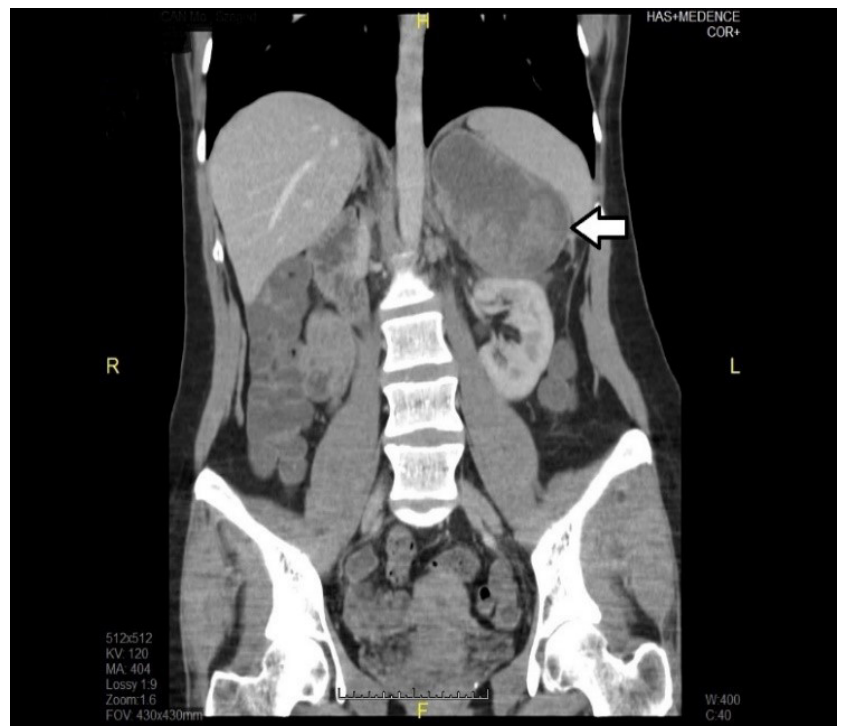

1. ábra Hasi CT-vizsgálat a bal mellékvesében $10 \times 7 \times 8 \mathrm{~cm}$-es, jól körülhatárolt elváltozást mutat

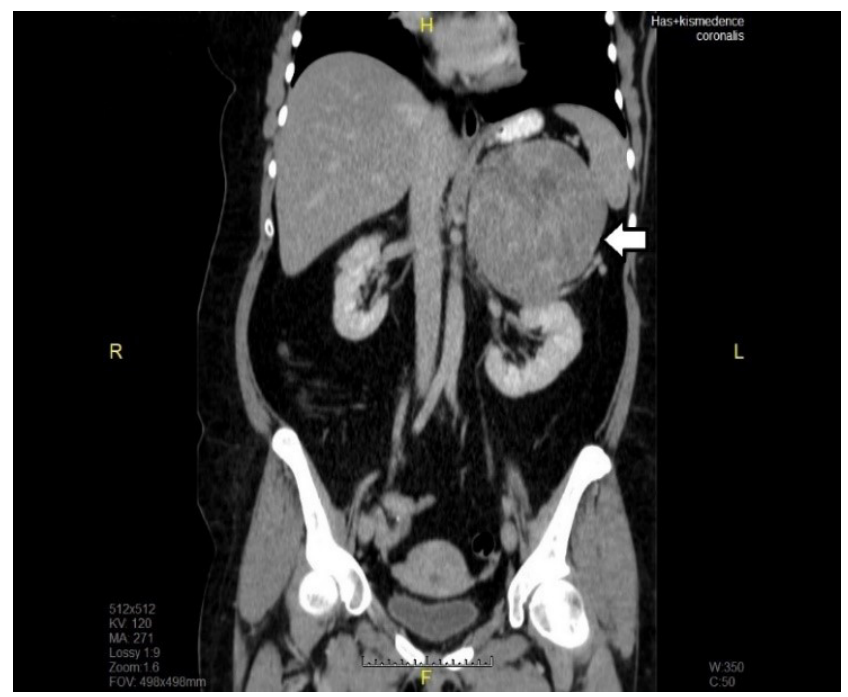

2. ábra

Hasi CT-vizsgálat bal oldalon, a mellékvesének megfelelően, egy, a pancreasfarkat diszlokáló, $10 \times 6 \times 13 \mathrm{~cm}$-es körülírt elváltozást mutat

A második esetben egy 46 éves nőbetegnél hypertonia miatt indult kivizsgálás. Az elvégzett hasi ultrahangvizsgálaton retroperitonealisan elhelyezkedő daganat látszott. A beteg a felvételt megelőző fél évben $6 \mathrm{~kg}$-ot fogyott. Hormonálisaktivitás-mérés során a kortizolértékek magasabbak voltak, a kortizol napi ritmus hiányzott, az értékek dexamethasonnal nem voltak szupprimálhatóak. Hasi CT-vizsgálaton a bal oldali retroperitoneumban a pancreasfarkat diszlokáló, $10 \times 6 \times 13 \mathrm{~cm}$ kiterjedésú szolid terime jelent meg (2. ábra).

A 62 éves férfi betegünknél epés panaszok kivizsgálása kapcsán végzett hasi ultrahangvizsgálaton bal oldali retroperitonealis terime gyanúja vetődött fel, amelyet hasi CT-vizsgálat $(4,8 \times 6,3 \times 7 \mathrm{~cm})$ is megerősített (3. ábra). 


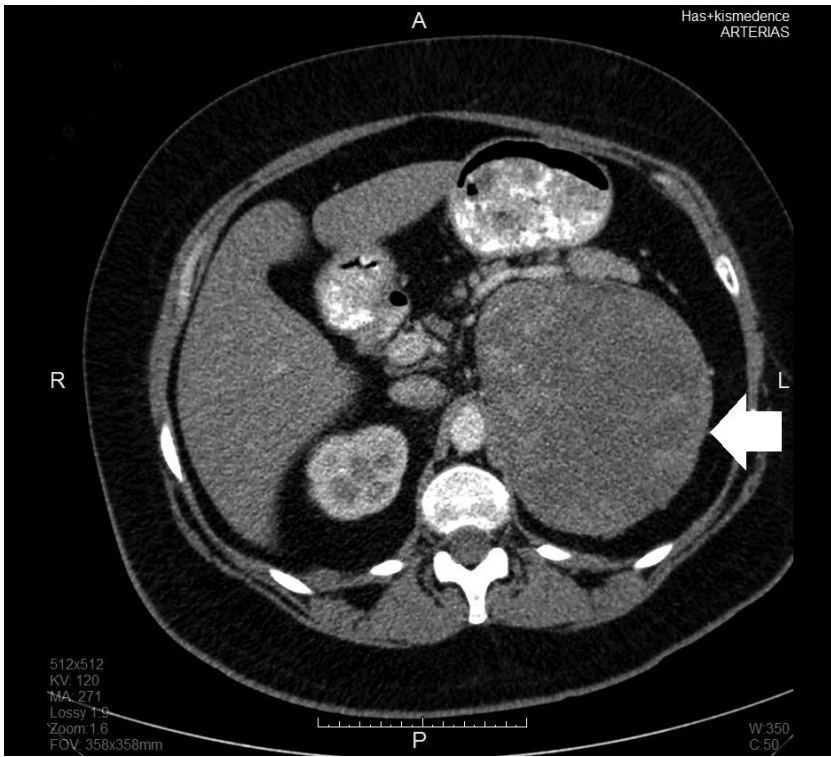

3. ábra

Hasi CT-vizsgálat egy bal oldali 4,8 ×6,3 ×7 cm-es, körülhatárolt retroperitonealis elváltozást mutat

A funkcionális vizsgálatok normális aldoszteron-, valamint szérumnátrium- és -káliumszinteket igazoltak. Hyperandrogenismus nem igazolódott, azonban a szérum-ACTH (adrenokortikotrop hormon) -szint alacsony volt. A vanil-mandulasav (VMS) -érték nem zárta ki pheochromocytoma lehetőségét, így alfa-blokkoló kezelés indult. MEN (multiplex endokrin neoplasia) -szürés kapcsán emelkedett kalcitoninszintet észleltek, azonban a pajzsmirigy és mellékpajzsmirigy ultrahangvizsgálata negatív volt. Kiemelendő, hogy a diagnózist megelőző másfél évben diétával $70 \mathrm{~kg}$-ot fogyott, ezt követően a korábbi hypertonia, illetve gyógyszeresen kezelt diabetes, valamint vércukorértékek jelentősen javultak.

\section{Sebészi kezelés}

A preoperatív ASA (American Society of Anesthesiologists) -score alapján az első két nőbeteg ASA 2, harmadik, férfi betegünk pedig ASA 3 csoportba tartozott. A három beteg átlag-BMI-je 31 volt. Mindhárom beteg esetében, a radiológiai vizsgálatok alapján, a daganatok jól körülhatároltak voltak, extrakapszuláris tumorterjedés, valamint távoli metasztázisképződés sem volt igazolható, mindezek alapján laparoszkópos mütét mellett döntöttünk. A mütétet megelőző napon a betegek per os folyadékot kaptak, bélelőkészítést nem alkalmaztunk.

\section{Mütéti technika}

Mindhárom esetben intratrachealis narkózisban végeztük a beavatkozásokat. A mütéteket minden esetben jobb oldali semilateralis fektetési pozícióban, transperitonealis behatolásból végeztük, három port (két darab 10 mm-es: kamera- és eszközport, egy darab 5 mm-es: eszközport) behelyezésével. A mütét során a colon descendens mobilizálását, valamint a ligamentum splenorenale disszekcióját követően Ligasure segítségével mobilizáltuk a bal oldali mellékvesét, illetve az abból kiinduló nagyméretű tumort. A suprarenalis ereket Hem-o-lok klippek felhelyezését követően vágtuk át. A mútét során a daganat környezetére való terjedését, extracapsularis propagatióra utaló jeleket nem észleltünk. Ezt követően a már szabadon mozgatható tumort intraabdominalisan „Endobag”-be helyeztük (4. ábra), és kiegészítő Pfannenstiel-metszésen keresztül en bloc eltávolítottuk a hasüregból. Az átlagos mútéti idő 126,66 perc volt (70, 180,130 perc), az átlagos intraoperatív vérveszteség $150 \mathrm{ml}$ volt $(100 \mathrm{ml}, 250 \mathrm{ml}, 100 \mathrm{ml})$.

\section{Posztoperatív szak, utókezelés és utánkövetés}

A mütétet követően a betegek az első két napban NSAID (Paracetamol, Diclofenac, Algopyrin) fájdalomcsillapítókat kaptak, ezt követően nem igényeltek analgetikumokat. A per os folyadékbevitelt a mútét napján megkezdtük. Posztoperatív ileus egyik esetben sem fordult elő. A kórházi tartózkodás három-öt nap között változott (átlag: négy nap). A szövettani vizsgálat két esetben adrenocorticalis carcinomát (I, II), egy esetben pedig neurofibromát (III) igazolt. A tumor átmérője mindhárom esetben $10 \mathrm{~cm}$ feletti volt (I: $13 \times 9 \times 8 \mathrm{~cm}$, II: $14,5 \times$ $11,4 \times 10 \mathrm{~cm}$, III: $11 \times 6,5 \times 3,7 \mathrm{~cm})$. Mindegyik esetben $\mathrm{R} 0$ reszekciót végeztünk. Az első beteg a tokérintettséget is mutató ACC miatt adjuváns kezelésként a bal mellékvese tumorágyába $25 \times 2$ Gy irradiációt kapott. A második beteg esetében adjuváns irradiációra nem volt szükség, a harmadik betegnél pedig a benignus szövettan miatt onkológiai kezelés nem volt szükséges. Az átlagban 24 hónapos utánkövetés során mindhárom betegnél kontroll hasi CT-, illetve MR (magnetic resonance imaging) -vizsgálatok során recidíva, lokális vagy távoli metasztázis nem igazolódott. Az utánkövetés során mindhárom beteg rendszeres endokrinológiai kontroll alatt állt.

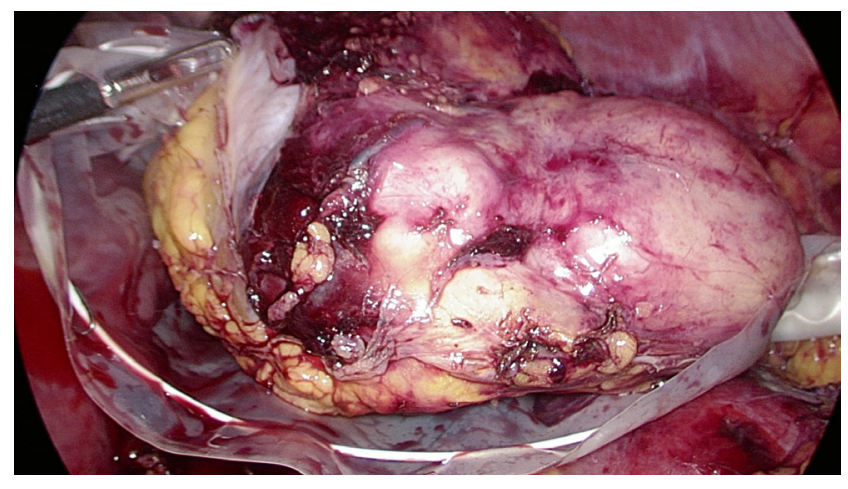

4. ábra | Endobag”-be helyezett, szabaddá preparált mellékvesetumor 


\section{Megbeszélés}

A mellékvese-elváltozások sebészi kezelésében a laparoszkópos technika az utóbbi években „gold standarddá" lépett elő [8]. A módszer számos előnye közé tartozik többek között az alacsony perioperatív mortalitás, rövidebb kórházi tartózkodás, csökkent fájdalomcsillapító-igény, előnyös kozmetikai eredmény, valamint a csökkent intraoperatív vérveszteség $[9,10]$. Ezek mellett a TP-módszer alkalmazása számos mútéttechnikai előnynyel is jár, amelyek közül a legfontosabb az intraoperatív manipulációt elősegítő kiterjedt és a hasi sebészek számára ismerős anatómia, illetve jobb vizualizáció [11]. Mindazonáltal a nagyméretü ( $>6 \mathrm{~cm}$ ) és fö́ként az óriás $(>10 \mathrm{~cm})$ mellékvese-elváltozások MI-eltávolítása továbbra is komoly kihívást jelent, nemcsak a tumorok méretéből fakadóan, hanem azáltal is, hogy a méret növekedésével a malignitás esélye is növekszik [12]. Az NIH (National Institutes of Health) közleménye szerint a 4 cm alatti elváltozások 2\%-a, a 41-60 mm közöttiek 6\%-a, illetve a $6 \mathrm{~cm}$ felettiek 25\%-a malignus [13]. Önmagában a méret azonban nem megbízható predikciós faktor, hiszen számos benignus elváltozás (adenoma) is lehet $6 \mathrm{~cm}$ feletti, így - mint ahogy az vizsgálati anyagunkban is történt - a mútétet meg kell, hogy előzze a preoperatív kivizsgálás szerves részét képező képalkotó vizsgálat, lehetőség szerint kontrasztos hasi CT vagy MRI. A felvételeken megjelenhetnek malignitásra jellegzetes elváltozások - úgymint szabálytalan tumorszél, lokális invázió vagy a mellékvese körüli szövetek infiltrációja -, amelyek nagyban hozzájárulnak a preoperatív diagnosztikához [14]. A végső diagnózis felállítása azonban az anamnézis, fizikális vizsgálat, hormonálisan aktív tumorok esetében endokrinológiai szakvizsgálat eredményei, valamint CT/MRI eredmények alapján kell, hogy megtörténjen [15]. A TP-módszer alkalmazásában továbbra is az óriás méretü és egyben malignus tumorok eltávolítása jelenti a legnagyobb kihívást.

Az ACC egy ritkán előforduló malignoma, amely többnyire nóket érint, és amelynek diagnózisa gyakran már előrehaladott állapotban történik [16]. Vizsgálatunk során két nőbetegnél igazolt a szövettan adrenocorticalis carcinomát. ACC esetében az ötéves túlélés R0 reszekció után 50-60\%, azonban még komplett eltávolítás esetén is igen magas a recidíva, valamint metasztázisok előfordulásának aránya (átlagosan 23\%) [17, 18]. A TP-módszer tekintetében a SAGES (Society of American Gastrointestinal and Endoscopic Surgeons) ajánlása korábban mindössze a $6 \mathrm{~cm}$-nél kisebb benignus elváltozások endoszkópos eltávolítására terjedt ki, arra hivatkozva, hogy nagyobb méretú, illetve potenciálisan malignus tumorok esetében a nem megfelelő onkológiai radikalitás esélye igen magas [19]. Az ESES (European Society of Endocrine Surgeons) azonban felülvizsgálta a fentebb említett álláspontot és ajánlásába foglalta, miszerint a $10 \mathrm{~cm}$-t meg nem haladó I. és II. stádiumú ACC- $\mathrm{k}$ ellátására a TP-módszer is biztonsággal használható [20].

Malignus mellékvese-daganatok laparoszkópos eltávolítása esetén a kórházi tartózkodás szignifikánsan rövidebb, mint nyitott mútéteket követően [21]. Megfelelő laparoszkópos tapasztalat esetén a nagyobb méretü elváltozások eltávolítása nem hosszabbítja meg jelentősen a mútéti időt, és nem növeli a vérveszteséget sem. Három esetünknél a mútéti idő 70-130 perc között változott (átlag: 126,66 perc). A Porpiglia és mtsai által közölt vizsgálatban, amelynek során 126 TP-adrenalectomián átesett beteget vizsgáltak, az átlagos mútéti idő 139 perc volt, azonban nem szabad figyelmen kívül hagyni, hogy a tanulmányban $<4 \mathrm{~cm}$-es elváltozások szerepeltek, amelyek közül a legnagyobb tumor kiterjedése $11 \mathrm{~cm}$ volt [22]. Vizsgálatunkban a második beteg esetében eltávolított malignus elváltozás több mint 14,5 cm kiterjedésű volt, ennek ellenére konverzióra nem kényszerültünk, és a beavatkozás hossza, valamint a mútét alatti vérveszteség is elfogadható eredményeket mutatott (mútéti idő: 180 perc, intraoperatív vérveszteség: $250 \mathrm{ml}$ ). Az Asari és mtsai által közreadott, 289, TP-adrenalectomián átesett beteget magában foglaló tanulmány szerint a $6 \mathrm{~cm}$ nél nagyobb tumorok esetében sem találtak szignifikánsan hosszabb mútéti időt, mint a kisebb elváltozásoknál [23]. A mútét alatti vérveszteség nem állt egyenes arányban az elváltozások nagyságával, így a posztoperatív szakban nem volt szükség vértranszfúzió adására. E tekintetben egy 35, TP-adrenalectomián átesett beteget elemző vizsgálat sem talált szignifikáns különbséget a $>8$ $\mathrm{cm}$, illetve annál kisebb elváltozások során feljegyzett intraoperatív vérveszteség terén [24]. Vizsgálatunkban az eltávolított specimenek mérete meghaladta a $10 \mathrm{~cm}-\mathrm{t}$, azonban ennek ellenére az intraoperatív vérveszteség minimális maradt (átlag: $150 \mathrm{ml}$ ). Tekintettel az átlagon felüli specimenméretekre, a tumorok eltávolítására mindhárom esetben a beteget kismértékben megterhelő és kozmetikailag is jó eredményt adó Pfannenstiel-metszést alkalmaztuk. A hasfalon keresztül a specimen eltávolítására számos lehetőség kínálkozik, úgymint a különböző pozícióban lévő munkaportok metszéseinek meghoszszabbításán keresztül (lateralis, periumbilicalis), illetve külön metszésből $[25,26]$. Mútéteink során a külön ejtett Pfannenstiel-metszést a biztonságos tumoreltávolítás, az alacsony posztoperatív herniák előfordulása, valamint a jó kozmetikai eredmények miatt választottuk.

Fontos hangsúlyoznunk, hogy habár vizsgálatunk is alátámasztja a laparoszkópos transperitonealis adrenalectomiák alkalmazhatóságát malignus daganatok esetében is, a komplett, R0 reszekciók kivitelezése képezi a sebészi ellátás legfontosabb részét. Inkomplett reszekciók után a medián túlélés kevesebb, mint 12 hónap [27]. A túlélést, valamint a lokális recidíva arányát befolyásoló másik fontos tényezó az enkapszulált elváltozások esetében a tok intaktságának megtartása. A tok sérülésének lehetôsége a daganat méretével egyenes arányban növekszik [28], ezért a preoperatív képalkotó vizsgálatoknak kiemelt sze- 
repe van annak eldöntésében, hogy a daganat milyen mértékben infiltrálja környezetét (szomszédos szervek, vena cava inferior stb.), és így annak megítélésében is, hogy az adott elváltozás alkalmas-e a laparoszkópos technikára. A legfrissebb systematic review alapján, amely több mint 1000 beteg mútéti eredményeit hasonlította össze, megállapítható, hogy a laparoszkópos technika nem növeli az onkológiai kockázatot (helyi kiújulás, peritonealis szórás, recidívák megjelenésének ideje, tumortoksérülés), I/II. stádiumú tumorok esetén a nyitott technikával összehasonlítva [29]. Ezenkívül van néhány fontos megállapítás, amelyeket mindenféleképpen figyelembe kell venni a minimálisan invazív technika alkalmazásánál: $1.10 \mathrm{~cm}$ felett a daganatszóródás és a toksérülés aránya emelkedik (onkológiai kockázat!); 2. amennyiben a daganat környezetre való terjedése észlelhető, azonnali konverzió ajánlott; 3. csak gyakorlott sebész/team végezze a mütétet (minimum 40-50 mütét); 4. retroperitoneoszkópos (hátsó behatolásból végzett) mütét nem ajánlott. Az általunk sikeresen operált esetekben a daganat környezetre való terjedésére sem mútét előtt, sem mútét alatt nem volt gyanú; a mütétekre több mint 150 laparoszkópos adrenalectomia után vállalkoztunk, amely mütéti szám biztosította a megfelelő sebészi tapasztalatot. Annak ellenére, hogy a retroperitoneoszkópos mütéti eljárással is van gyakorlatunk [5], egyértelmú volt, hogy eseteink kapcsán a transperitonealis technikát kell alkalmaznunk a sikeres és biztonságos eltávolítás érdekében.

Onkológiailag sikeres mütét esetén is nagyon fontos a megfelelő utánkövetés a helyi vagy szisztémás kiújulás észlelése céljából. Pozitív reszekciós szél, toksérülés, illetve előrehaladott stádium (III/IV.) növeli a helyi kiújulás, illetve tumorszóródás esélyét [30]. Eseteinkben a végleges patológiai feldolgozás mindhárom beteg esetében R0 reszekciót igazolt, az átlag 24 hónapos utánkövetés alatt a CT-, illetve MR-vizsgálatok sem peritonealis, sem port site, sem pedig távoli áttétképződést nem igazoltak.

Habár hazánkban több munkacsoport is sikeresen alkalmazza a minimálisan invazív technikát $[3,10,15]$, nagyméretú, malignus daganatok laparoszkópos úton való eltávolításáról, illetve azok utánkövetésével kapcsolatos eredményekről nem találtunk adatokat.

\section{Következtetés}

Mütéteink sikere támogatja a transperitonealis adrenalectomia már korábban is széles indikációs körének bővítését. Megállapítható, hogy nemcsak a nagyméretű benignus, hanem malignus, illetve malignitásra gyanús mellékvese-elváltozásoknál is, megfelelő feltételek megléte mellett, a transperitonealis adrenalectomia biztonsággal, az onkológiai irányelveknek maradéktalanul eleget téve alkalmazható eljárás. A daganat környezetre való terjedése, a sebészi team gyakorlatlansága kontraindikációja a laparoszkópos technikának.
Anyagi támogatás: A közlemény megírása anyagi támogatásban nem részesült.

Szerzôi munkamegosztás: O. A.: Kutatómunka, az irodalom áttekintése, a kézirat összeállítása és megírása. P. A.: Technikai tanácsadás. B. B.: Statisztikai elemzés, formai korrektúra. Á. Sz.: Adatgyújtés. S. Zs.: Technikai tanácsadás, irodalmi adatgyüjtés. L. Gy.: A kézirat szakmai lektorálása, szakmai tanácsadás. A cikk végleges változatát valamennyi szerző elolvasta és jóváhagyta.

Érdekeltségek: A szerzőknek nincsenek érdekeltségeik.

\section{Irodalom}

[1] Mege D, Taieb D, Lowery A, et al. Contemporary review of large adrenal tumors in a tertiary referral center. Anticancer Res. 2014; 34: 2581-2588.

[2] Gagner M, Pomp A, Heniford BT, et al. Laparoscopic adrenalectomy lessons learned from 100 consecutive procedures. Ann Surg. 1997; 226: 238-247.

[3] Vereczkei A, Molnár Á, Horváth ÖP. Minimally invasive technique as the gold standard of adrenal surgery. [A minimálisan invazív technika mint a mellékvese-sebészet „gold standardja”.] Magy Seb. 2012; 65: 365-369. [Hungarian]

[4] Walz MK, Peitgen K, Krause U, et al. Dorsal retroperitoneoscopic adrenalectomy - a new surgical technique. Zentralbl Chir. 1995; 120: 53-58.

[5] Balogh Á, Varga L, Julesz J, et al. Minimally invasive adrenalectomy with posterior retroperitoneoscopy. [Adrenalectomia minimálisan invazív formája hátsó retroperitoneoszkópos behatolásból.] Orv Hetil. 2000; 141: 845-848. [Hungarian]

[6] Liao CH, Chueh SC, Lai MK, et al. Laparoscopic adrenalectomy for potentially malignant adrenal tumors greater than 5 centimeters. J Clin Endocrinol Metab. 2006; 91: 3080-3083.

[7] Palazzo FF, Sebag F, Sierra M, et al. Long-term outcome following laparoscopic adrenalectomy for large solid adrenal cortex tumors. World J Surg. 2006; 330: 893-898.

[8] Gagner M. Laparoscopic adrenalectomy. Surg Clin North Am. 1996; 76: 523-537.

[9] Wang HS, Li CC, Chou YH, et al. Comparison of laparoscopic adrenalectomy with open surgery for adrenal tumors. Kaohsiung J Med Sci. 2009; 25: 438.e44.

[10] Juhász F, Kanyári Zs, Győry F, et al. Change in the surgical treatment of benign adrenal gland tumors. Laparoscopic adrenalectomy. [Szemlélet- és stratégiaváltás a jóindulatú mellékvese-daganatok sebészi kezelésében. Laparoszkópos adrenalectomia.] Magy Seb. 2001; 54: 75-79. [Hungarian]

[11] Al-Otaibi KM. Laparoscopic adrenalectomy: 10 years experience. Urol Ann. 2012; 4: 94-97.

[12] Hobart MG, Gill IS, Schweizer D, et al. Laparoscopic adrenalectomy for large-volume $(\geq 5 \mathrm{~cm})$ adrenal masses. J Endourol. 2000; 14: 149-154.

[13] NIH state-of-the-science statement on management of the clinically inapparent adrenal mass ("incidentaloma"). NIH Consens State Sci Statements 2002; 19: 1-25.

[14] Gumbs AA, Gagner M. Laparoscopic adrenalectomy. Best Pract Res Clin Endocrinol Metab. 2006; 20: 483-499.

[15] Horányi J, Tihanyi T, Szlávik R, et al. Laparoscopic adrenalectomy in the treatment of adrenal gland primary and secondary malignancies. [Laparoszkópos adrenalektomia a mellékvese primer és szekunder malignomáinak kezelésében.] Magy Seb. 2002; 55: 153. [Hungarian]

[16] Fassnacht M, Johanssen S, Quinkler M, et al. Limited prognostic value of the 2004 International Union Against Cancer staging 
classification for adrenocortical carcinoma: proposal for a Revised TNM Classification. Cancer 2009; 115: 243-250.

[17] Allolio B, Fassnacht M. Adrenocortical carcinoma: clinical update. J Clin Endocrinol Metab. 2006; 91: 2027-2037.

[18] Crucitti F, Bellantone R, Ferrante A, et al., The ACC Italian Registry Study Group. The Italian Registry for Adrenal Cortical Carcinoma: analysis of a multiinstituitional series of 129 patients. Surgery 1996; 119: 161-170.

[19] Stefanidis D, Goldfarb M, Kercher KW, et al. SAGES guidelines for minimally invasive treatment of adrenal pathology. Surg Endosc. 2013; 27: 3960-3980.

[20] Henry JF, Peix JL, Kraimps JL. Positional statement of the European Society of Endocrine Surgeons (ESES) on malignant adrenal tumors. Langenbecks Arch Surg. 2012; 397: 145-146.

[21] Autorino R, Bove P, De Sio M, et al. Open versus laparoscopic adrenalectomy for adrenocortical carcinoma: A meta-analysis of surgical and oncological outcomes. Ann Surg Oncol. 2016; 23: 1195-1202.

[22] Porpiglia F, Destefanis P, Fiori C, et al. Does adrenal mass size really affect safety ad effectiveness of laparoscopic adrenalectomy? Urol. 2002; 60: 801-805.

[23] Asari R, Koperek O, Niederle B. Endoscopic adrenalectomy in large adrenal tumors. Surgery 2012; 152: 41-49.
[24] Bozkurt IH, Arslan M, Yonguc T, et al. Laparoscopic adrenalectomy for large adrenal masses: Is it really more complicated? Kaohsiung J Med Sci. 2015; 31: 644-648.

[25] Abraham GP, Siddaiah AT, Das K, et al. Laparoscopic extirpation of giant adrenal ganglioneuroma. J Minim Access Surg. 2014; 10: 45-47.

[26] Chaudhary R, Deshmukh A, Singh K, et al. Laparoscopic resection of a large $(11 \mathrm{~cm})$ adrenal phaeochromocytoma. BMJ Case Rep. 2011; 2011: bcr 0820114575.

[27] Pedullà G, Sapienza P, Paliotta A, et al. Surgical considerations for removal of giant tumor of the right adrenal. Anticancer Res. 2014; 34: 5087-5090.

[28] Miller BS, Ammori JB, Gauger PG, et al. Laparoscopic resection is inappropriate in patients with known or suspected adrenocortical carcinoma. World J Surg. 2010; 34: 1380-1385.

[29] Machado NO, AlQadhi H, AlWahaibi K, et al. Laparoscopic adrenalectomy for large adrenocortical carcinoma. JSLS 2015; 19: pii: e2015.00036.

[30] Carnaille B. Adrenocortical carcinoma: which surgical approach? Langenbecks Arch Surg. 2012; 397: 195-199.

(Lázár György dr., Szeged, Semmelweis u. 8., 6725 e-mail: gylazar@gmail.com)

\title{
"Non vi, sed arte!" \\ (Nem erőből, hanem művészetből!)
}

\section{Az Orvosi Hetilap 2017, 158, 1560. oldalán (39. szám) megjelent OH-Kvízre három helyes megfejtés érkezett.}

\author{
A beküldők: Dr. Bíró László (Budapest), Dr. Janik Leonárd (Budapest) \\ és Dr. Somogyi Erzsébet (Miskolc). \\ A nyerteseknek szívből gratulálunk. \\ Nyereményüket - egy, az Akadémiai Kiadó webáruházában \\ kedvezményes vásárlásra jogosító kupont - e-mailen küldjük el.
}

